\section{"Mefaphysics themselves are but a dry romance"}

\author{
Uttara Natarajan, Tom Paulin, and
} Duncan Wu, ed., Metaphysical Hazlitt: Bicentenary Essays (London and New York: Routledge, 2005)

C. I. Patterson, Jr., in an article of 1981 , concluded that "the need for thorough reappraisal of [Hazlitt's] criticism and his present high standing as a critic seems evident." ${ }^{1}$ What happened was, however, exactly the opposite, since the eighties proved to be the period when Hazlitt started to achieve an increasingly stable "standing" among the canonical writers of the romantic period. David Bromwich's foundational study appeared in 1983; then came Stanley Jones's Life in 1989, which was followed by Uttara Nattarajan's systematic account of Hazlitt's philosophy in 1998, and Tom Paulin's analysis of his style in the same year; 1998 also saw the appearance of a nine-volume critical edition of the Selected Writings of William Hazlitt by Duncan Wu. A new biography, by A. C. Grayling, appeared in 2001, to mention only the most important publications. ${ }^{2}$ Metaphysical Hazlitt, by the sheer fact that a volume of articles by the most distinguished experts was published by Routledge on the bicentenary of the publication of Hazlitt's first book (in 1805) shows that the efforts of these scholars have not been in vain.

What, then, is Hazlitt's An Essay on the Principles of Human Action: Being an Argument in favour of the Natural Disinterestedness of the Human Mind? This is the work of a very young man (he was planning the book already as a teenager), and his only attempt to produce something like a treatise in an eighteenth-century mode. He formulates very precisely the problem to which he is seeking an answer: "The question is whether the individual is the same being in such sort or manner as that he has an equal, absolute interest in every thing relating to himself, or that his future impressions affect him as much and impel him to action with the same mechanical force as if they were actually present." 3

The answer to this complex question is a definite no. Simplifying the argument rather crudely, he suggests that the individual is not "the same being" but many different beings. We are connected to our past selves through memory, to the present through sensation, and to the future through imagination. Now we cannot have the memories of anyone else, nor can we share their sensations, but the imagination that carries me out of my present self into my future self is the same faculty that can carry me out of myself into someone else. And since all action (and all our volitions behind it) is directed at 
the future, the root of selfish and benevolent behaviour is the same.

The authors of this volume, by focusing on this single philosophical work, can disregard many important issues in Hazlitt-scholarship. His participation in the massive print culture of the age, 4 his political journalism, the generic difference between this and most of his later essays, 5 or the gender implications of his writings attract little or no attention, although Hazlitt seemed almost to beg this last by his preposterous remark that "no woman ever read or would ever comprehend the meaning of" the Essay (quoted by Natarajan, p. 4- may this have anything to do with the fact that ten out of eleven contributors are men?). The overall impression that the volume makes is that its writers have accepted Natarajan's warning, in her monograph on Hazlitt, against the over-domination of historicist readings. ${ }^{6}$ Most of the essays can be read within the tradition of the history of ideas. The articles are arranged into three sections: those in the first concentrate on the Essay itself, and its place in Hazlitt's oeuvre, in the second we have three papers that focus on Hazlitt's influence on his better-known contemporaries (especially Wordsworth and Shelley, the much-discussed case of Keats receives little attention here), and the final three essays compare him to major philosophers either of his era, or our own.
The first section begins with a detailed delineation of the Essay's arguments by David Bromwich. He has already analysed this work in his monograph on Hazlitt, and, he claims that he intends to correct the interpretation there given, because he then underestimated the importance of the theme of "instinctive attraction to the good" in that book (17). In fact, he did attend to the problem there, but regarded it as a contradiction in the Essay, since, in his interpretation, it contains proofs for the possibility of disinterestedness mostly from our psychology, whereas, at certain moments, this is interrupted by arguments from the nature of the objects of our action. If the object is interesting in itself, "then there could be no virtue in unselfishness." 7 Here, however, he finds this explicable in light of the significance of the idea of liberty in Hazlitt's political writings, which, he suggests, is the equivalent of the abstract good of the metaphysical work.

The second paper, by James Mulvihill, focuses on the account of identity in the Essay. Mulvihill concludes that Hazlitt's is a "dualistic proposition:" "identity is both compound and distinct - never the same from moment to moment, yet the continuing focus of consciousness and perception." (41) This is basically the psychological counterpart of Natarajan's account of "the aggregate" in Hazlittian epistemology, which 
replaces traditional concepts of abstract ideas and universality. She defines it as "a universal or general reality, each of whose components is individual and particular."8 Mulvihill contends that this theory of identity permeates the whole of Hazlitt's writings from his theatrical criticism to the Spirit of the Age. The question of the unity of Hazlitt's oeuvre is a contended one. Opinions vary from Natarajan, who finds a "quite astonishing consistency" in the "complexity of Hazlitt's thought" to Dart, who opts for its "selfcontradictory" nature, and Whale, in whose judgment it "defies system or theory." 9 Mulvihill's is thus an interesting, sophisticated in-between position.

In the next essay Philip Davis takes up the idea from the Essay that the philosophy of self-love, propounded by Hobbes and his followers, is nothing but a secondary consideration which is preceded by the instantaneous workings of the imagination, characterised by unsurpassed swiftness and incalculability, which results from the ease with which it moves between self and other. Davis points out that Hazlitt found the best example of natural disinterestedness in Shakespeare, who could identify with all of his characters at the same time, and could also create a dramatic field in which the dynamics of the imaginative process could have full play. The problem with this analysis is not so much that much of its argu- ment coincides with Tom Paulin's in The Day-star of Liberty (1998) - where motion and dynamism were already central concerns, both in the analysis of the philosophical bases of Hazlitt's thinking and in the description of his style - but that it fails to address the crucial question, posed by Uttara Natarajan, whether Shakespeare is actually the prime example for Hazlitt as to the workings of the imagination, or rather, as she has suggested, "the glorious exception." ${ }^{10}$ This is a crucial issue partly because it is decisive as to the continuity between Hazlitt's and Keats' thinking about poetry.

John Whale's is one of the healthily sceptical voices in a volume in which few of the authors dare openly criticise Hazlitt; this is probably the result of the urge behind the whole enterprise to foster his recognition.. The chapter on Hazlitt in his book, Imagination Under Pressure is based on the conviction that the essayist's "aesthetics are caught between sympathy and power, the learned and the vulgar, the body and ideas." "While in that book the first two pairs are in the foreground, here he focuses on the last one: the suppositional selfishness of sexual desire as a threat to the conception of disinterestedness in the Essay. He points out that in the early writings, and especially in the Reply to Malthus, Hazlitt seems to believe in the "culturally constructed nature of sexuality" (59), while this 
belief evaporates altogether by the time he comes to write his 'A Letter to my Son' (1822), where love is represented as standing in direct contrast with the world of culture and is mostly seen as an issue of sheer physical desire. One should maybe emphasise that although Hazlitt often allows his personal disappointment to distort his statements concerning the relation of the sexes, even to the point of open sexism, still the complex and contradictory nature of human motivations will remain a constant theme in his writings, which may preserve something of the subtlety of his earlier remarks concerning the nature of sexual desire.

Paul Hamilton's article, which concludes the first section of the book, examines the relationship between the private and the public in Hazlitt's oeuvre. In his youthful Essay he argued for the possibility of an imaginative merger between the two, while in his political writings one pillar of his Jacobinical outlook was the belief in the potential of any private person to gain an important public role, which goes a long a long way to explain his admiration of Napoleon as well. This is a central theme in his criticism of contemporary poetry also, which Hamilton exemplifies by quoting from Hazlitt's readings of Shelley ("eaten up with personality") and Wordsworth. "Briefly, there is nothing poetical in the spirit of the age, and so creative minds like Words- worth are forced into the untenable egotism of pure Dissent" (73-74). In contrast to Natarajan, who claimed in Hazlitt and the Reach of Sense that egotism, to the essayist's mind, was inseparable from the nature of poetry; Hamilton convincingly presents this problem as part of his criticism of modernity only.

The second part begins with one of the most exciting pieces of the whole collection, in which Duncan Wu reconstructs, going beyond the account given in "My First Acquaintance with Poets," the events of the three weeks when Hazlitt stayed with Wordsworth and Coleridge at Nether Stowey and Alfoxden in 1798, and the disputes that took place there. Building on Uttara Natarajan's account of Hazlitt's philosophy as emphasising the independent powers of the human mind and being in a significant part the secularization of Unitarian theological doctrine, he shows that Hazlitt was in the unique position not only to become acquainted (later) with the Two-Part Prelude, but to offer a criticism that significantly challenges the whole philosophy that was to sustain "The Recluse." Wu analyses in detail how Hazlitt's concept of the empowered mind clashed with the idea of "wise passiveness" that was to be central to the necessitarian theme of the grand philosophical poem, and how his atheism provoked both Coleridge's Unitar- 
ian faith and Wordsworth's "mystic perception of the natural world" (94). He makes us aware that the "exceptionally well read" (89) Hazlitt was "even at the tender age of twenty ... fully qualified to advise on 'The Recluse'" (85), and that Wordsworth took him seriously enough to have to reassure himself in a number of poems that Hazlitt cannot have been right after all. ${ }^{12}$

Tom Paulin is probably the only person who is able to relish everything that Hazlitt wrote, from his masculinist outbursts to his anti-Catholicism. Here he begins his chapter by quoting a very long footnote from the Essay in which Hazlitt criticises, in epistemological terms, the superficiality of the French character. The French seem to be unable to create connections between perceptions and the abstractions of the mind: either all is abstract as in the rhetoric of their tragedies, or there is but a free-floating succession of unconnected perceptions, a fault Hazlitt usually attributes to British philosophy from Hobbesian sensualism to Hartley's associationalism. Paulin contends that the solution Hazlitt offers to this dilemma is very similar to Wordsworth's concept of the "spots of time"; he also points out that the two authors may have borrowed certain images from each other. One might say that Paulin, in his zeal to "restore [Hazlitt] to his rightful place as philosopher, master critic, political journalist and unequalled prose stylist" (111) probably stretches the case for borrowings from Hazlitt too far, but he certainly does indicate a number of important parallels with Wordsworth, and, in passing, De Quincey.

Uttara Natarajan's study about Hazlitt's influence on Shelley's moral philosophy is the last in this section. She argues that there is an element in the connection that Shelley establishes between moral action and the imagination that is markedly different from the theories of David Hume and Adam Smith (other important influences), but shows important parallels with Hazlitt's speculations. In the theories of the two Scottish philosophers the imagination is always dependant upon the senses, and is ultimately self-regarding, Hazlitt, on the other hand, subordinates the senses to the mind, and describes a "circle of sympathy" that does not diminish with the distance from the self. Natarajan, not really interested in political implications, is satisfied with pointing out the structural parallels and differences in these moral philosophies, and does not add that the relative weakness of the imagination in Hume and Smith largely contributes to the importance they accord to positive law, and the keeping up of inherited social structures, which is clearly unacceptable for the more radically minded romantics. It is comforting, however, to 
learn that there was a more creative interchange between the two writers than Hazlitt's dismissive statements about Shelley's poetry.

Tim Milnes's essay is the first of the last group that examine Hazlitt's Essay in the context of more established philosophers. Milnes, the other healthily sceptical contributor to the volume, has already written an article in which he unearths certain unresolved dilemmas in Hazlitt's oeuvre, caught, as he claims, between idealism and empiricism, without recourse to the solution already offered by Kant's transcendental philosophy. ${ }^{13}$ It would have benefited a collection of studies that argues for Hazlitt's recognition as a philosopher to try to face up to this challenge. In this essay he contrasts Hazlitt's and Bentham's theories of language, and contends that while the romantic essayist is constructing a metaphysics based on truth as the correspondence between mind and reality, the utilitarian philosopher manages to work himself free from metaphysics altogether by reducing the question of truth to questions of meaning. This goes against the grain of a tradition that, Milnes claims, we have inherited ultimately from John Stuart Mill, according to which the figurative, metaphorical language of romanticism effectively deconstructs the matter-of-fact empiricism of utilitarianism. On the contrary, in this case at least, it seems to be Bentham, and not Hazlitt, who better understands the performative nature of language.

Frederick Burwick, in his article, by far the toughest reading in the whole book, points out certain parallels between Schelling's (especially in his 1809 essay Of Human Freedom) and Hazlitt's concept of freedom. He emphasises that both were formulating their moral philosophies under similar political circumstances in the aftermath of the French Revolution, and the coming of the Napoleonic wars. Both responded to necessitarian arguments by a reconsideration of the concept of self, both were informed by the contemporary science of the brain, and both believed in the disinterestedness of the mind. Obviously, in this case it is only possible to speak about parallels; influence - either way - is out of the question.

Grayling, in the final essay of the book, examines the relationship between the early Essay's defence of disinterestedness, and the more pessimistic analysis of our egotistical tendencies in the later writings. I find the contrast somewhat artificial, since Hazlitt readily admits from the very beginning that there is a "strong and uneasy attachment to self which comes at last (in most minds) to overpower every generous feeling." 14 The Essay does not present an especially optimistic anthropology; it is only concerned to show that 
there is a theoretical possibility of disinterested action. Grayling argues that although there are places where Hazlitt takes a more extreme view, there is evidence enough to suggest that he understood the role "nurture" plays in the formation of a character, and he was also aware of the contradictory motivations behind our actions. Meanwhile, he compares Hazlitt's arguments with those of. P. F. Strawson (19192006). The latter philosopher is bestknown for his contributions to ordinary-language philosophy and metaphysics. Both thinkers seem to believe that awareness of my own mind, and awareness of that of others mutually presuppose one another. Self-love and benevolence, to put it plainly, are inseparable.

In conclusion, I can only say that anyone interested in the fortunes of Hazlitt has to welcome that we are able to see him now in his metaphysical guise as well. This book will certainly increase the readers' awareness that there are other reasons for studying Hazlitt's philosophy, than to understand more about the conceptual bases of his literary, art or social criticism, and his influence on the major poets of the period. Hazlitt's writings, these studies prove, can be taken seriously as an interesting contribution to the history of philosophy as well. I have to add nonetheless that it would be important to take the more conversational writ- ings just as seriously. One should note Gregory Dart's shrewd observation that "Hazlitt's essay on sympathy had failed, in a way, to be sympathetic." 15 It is possibly the later writings that realised, in their use of language, what the early Essay propounded in principle. The dialogical, controversial nature of these writings (which is a central theme in Jones's biography, to whose memory the volume is dedicated), and the unique way in which they incorporate quotations, perform disinterestedness as literary practice. The Hazlitt that emerges from these studies is certainly more recognisably a philosopher than the one that we are used to, but also a bit less colourful. Like the grey and white covers of the book.

Bálint Gárdos

\section{Notes}

1. Charles I. Patterson, Jr., "Hazlitt's Criticism in Retrospect," SEL 21 (1981), p. 663 .

2. David Bromwich, Hazlitt: The Mind of a Critic, 2nd edition (New Heaven and London: Yale UP, 1999); Stanley Jones, Hazlitt, A Life: From Winterslow to Frith Street (Oxford: OUP, 1989); Uttara Natarajan, Hazlitt and the Reach of Sense: Criticism, Morals, and the Metaphysics of Power. (Oxford: Clarendon Press, 1998); Tom Paulin, The Day-Star of Liberty: William Hazlitt's Radical Style (London: Faber \& Faber, 1998); William Hazlitt, Selected Writings of William Hazlitt, ed. Duncan $\mathrm{Wu}, 9$ vols. (London: Pickering \& Chatto, 1998); A. C. Grayling, The Quarrel of the 
Age: The Life and Times of William Hazlitt (London: Weidenfeld and Nicholson, 2001).

3. William Hazlitt, The Complete Works of William Hazlitt, ed. P. P. Howe, 21 vols. (London and Toronto: J. M. Dent, 1930-4), Vol. 1, p. 30.

4. The topic, for example, of an excellent chapter in Mark Parker's Literary Magazines and British Romanticism (Cambridge: CUP, 2001), 59-105.

5. Although Uttara Natarajan has suggested that the "familiar essay," even by the choice of its genre, can be understood as a philosophical statement. See Natarajan, "The Veil of Familiarity: Romantic Philosophy and the Familiar Essay," SiR 42 (2003) 27-56.

6. "[W]e are in some danger of forgetting that the history of events may not take precedence over the history of ideas. Nor is the second simply conflatable with the first" (Natarajan, Hazlitt and the Reach of Sense, p. 2).

7. Bromwich, p. 53.

8. Natarajan, p. 132.

9. Natarajan, p. 3; Gregory Dart, Rousseau, Robespierre and English Romanticism (Cambridge: CUP, 1999), p. 210; John Whale, Imagination under Pressure, 17891832: Aesthetics, Politics and Utility (Cambridge: CUP, 2000), p. 110.

10. Natarajan, p. 9.

11. Whale, p. 110.

12. On the topic of Hazlitt's training in philosophy we probably owe the best account to Wu as well. Duncan Wu, "'Polemical Divinity': William Hazlitt at the University of Glasgow," Romanticism 6 (2000) 163-177.
13. Tim Milnes, "Seeing in the Dark: Hazlitt's Immanent Idealism," SiR 39 (2000) 3-25.

14. Hazlitt, The Complete Works, Vol. 1, p. 42.

15. Dart, p. 216. 